\title{
2 Conceptualisation of advanced business services and offshoring
}

\subsection{Advanced business services and knowledge intensive business services}

White-collar jobs have been considered as based on specialised knowledge. Therefore it is natural to refer to them as knowledge-intensive services (KIS) or knowledgeintensive business services (KIBS). KIBS have been defined as "mainly concerned with providing knowledge-intensive inputs to the business processes of other organisations, including private and public sector clients” (Muller \& Doloreux, 2009). Probably, the most frequently used characteristics of KIBS have been proposed by Miles et al. (1995), who define them as:

- "rely heavily upon professional knowledge;

- either are themselves primary sources of information and knowledge (reports, training consultancy etc.);

- or use their knowledge to produce intermediary services for their clients' production processes (e.g. communication and computer services);

- are of competitive importance and supplied primarily to business".

The definitions were prepared over a decade ago and need an update taking into consideration the progress in technology and changes in the strategies of companies towards offshoring and outsourcing of knowledge-intensive tasks. Moreover, new types of business services emerged and were not included in the definitions. Additionally, KIBS have been treated as a part of "production process". There is a natural connotation with the manufacturing sector, what means that services are subordinated the production processes. Already in the late 1970s and early 1980s the role of so call higher-order producer services (HOPS) became crucial for Western economies (Coffey, 2000). Anyway, it is possible that the "production process" is understood as any kind of business activity that is aimed at making something, thus it can be also a service.

Miles et al. (1995) point at potential sources of the rise of KIBS. Among others, the business services firms are results of "spin-off” of services from larger organizations. This is related to the specialisation of new firms and possibilities to offer their services to wider range of clients, not only internally. Moreover, the changes in firms lead to structural reorganisations and some non-core activities were contracted out.

KIBS have played a significant and documented role in the development of economies, regions, cities, and companies. For instance, broadly defined business services have positively contributed to the competitiveness of other enterprises (Commission of the European Communities, 1998) and they have also become key 
advantages of companies operating in other industries. KIBS firms have also been very innovative because of high average innovation intensity (Kam \& Singh, 2004). Some also argue that improving competition conditions for the business services firms may have positive impact on the global position of the European economy (Roberts, 2003).

The definition and approach of Miles et al. (1995) does not encompass reorganisations that are aimed at consolidation of services within firms. These are frequently traditional professional services like accountancy, marketing or legal advices, which are not technology-based. This is the main characteristics of captive offshoring units. They were not originally technology-based, but they were technology-enabled. It means that thanks to the technology, firms could move support activities closely related with core-activities to distant locations. Moreover, they could organise a unit that serves function to many international locations.

KIBS and white-collar services are not perfect substitutes. Especially, when administrative or financial functions are embedded into a firm and spread across many units. What has changed recently, is that many of the business functions has been centralised and became the subject to dynamic technological changes. It all led to creating the new categories of business units, functions, and tasks. Therefore, it is necessary to introduce a new conceptual approach, which adapts benchmark understanding of KIS and KIBS to business reality.

Also a new naming is required to distinguish from the traditional understanding of business services with the high knowledge content. The notion of advanced business services (ABS) best describes the specifics of modern business functions and their organisation with respect to international division of labour. In the structure of ABS we can distinguish both domestic and foreign-owned enterprises. The majority of firms are foreign-owned, however there are also domestic firms that focus on establishing services centres.

The definition of electronic commerce can be also used to contextualise ABS. According to WTO (2020) the electronic commerce is understood as "production, distribution, marketing, sale or delivery of goods and services by electronic means". ABS could be also included in this very broad definition, however our focus here is more about the flow of data globally.

There have been the evolution of the notion of KIBS. It happened mostly due to the new opportunities for trading information-driven services across borders. Originally, KIBS were understood as local businesses, capable of creating knowledge, are selling their services to other firms. Frequently, there was a need for face-to-face contacts. Since the advancement of technology and emergence of new forms of organisations of firms, KIBS are undertaken within MNEs.

In the inception of the discussion on KIBS, they were seen without the context of international flows. Moreover, the analysis of location of ABS was predominantly focused on the geographic or regional development point of view. However, the rise of the communication technologies and improvement in management practices put 
KIBS into international context through offshoring. Actually, offshoring was a great milestone in the development of KIBS. Therefore, it is important to refer to KIBS that are enabled through offshoring as ABS. Despite the fact that ABS share many features with KIBS, it should be pointed that not all offshore supporting functions are knowledge-intensive. Moreover, the context is changing due to the automation and introducing artificial intelligence.

After studying the literature related to KIBS, it is surprising that the role of MNEs and FDI has been almost neglected. In most of the contributions there is no link between KIBS and international operations of MNEs. Even if the interactions between them are put into the context, it is rather assumed that KIBS firms and MNEs exist next to each other. KIBS are frequently treated as a facilitation tool for international business. We argue that KIBS firms would not exist without MNEs not only as clients, but also as providers. KIBS is not only about outsourcing or offshore outsourcing, but more importantly about captive offshoring. It means that MNEs do not only purchase knowledge-based services from external partners, but produce them within their own boundaries. We assume that KIBS are results of international operations firms, therefore it is necessary to analyse them in connection. We think that thanks to such an approach we will fill an important gap in the literature.

There may be a discussion if ABS are synonyms of KIBS. We argue that yes, but several distinctive characteristics of modern business services have to be included:

- International context,

- Footloose nature,

- Codified knowledge,

- Prone to automation,

- Enabled by technology,

- Embedded into business operations.

\subsection{Classification of business services}

The phenomenon of business services is not new in the economic and business analysis. Anyway, their understanding and thus classification is ambiguous. It brings numerous challenges to measurement and statistical analysis of services (Klimek \& Sass, 2019). The issue of classification of services is mainly related to their intangible nature and dynamic evolution of their provision. This is particularly the case for internationally tradable services and those of high knowledge content. Delineating between various categories of services is then necessary to analyse business operations of firms. Moreover, the classifications of services has been frequently based on the 
methodology built for classifying manufacturing operations (Silvestro, Fitzgerald, Johnston, \& Voss, 1992). They distinguish:

\section{- Professional services,}

- Service shop,

- Mass services.

The top category above is characterised by, among others, high input of human efforts, long contact, and discretion. However, thanks to the organisational and technological developments in recent years, the understanding of professional services does not have to include those elements, as some services can be executed without personal contacts, while the customisation can be achieved by using commoditised modules.

The use of official statistics in understanding of offshoring of knowledge-intensive services is of limited help, as advanced business services do not perfectly fit into any category of business services. From the perspective of classification, ABS are hybrids of several categories of services. The approach by analysts and officials vary between economies. Even in the case of V4 economies, there are significant discrepancies in naming and methodologies applied to comprehend these services.

Consequently, we aim at bringing the official classifications as close as possible to the business reality. The starting assumption about the classification is that it should bring the context of international tradability to knowledge-intensive business services. Thus, modes of international provision of services based on the regulations of WTO are linked to the operations of ABS firms (Table 2). Knowledge-intensive services, due to flexibility and complexity of their provision, do not fit only in one mode. The most relevant mode to deliver ABS is "Cross-border supply", which is directly related to the transfer of services across borders. This is the dominant mode of

Table 2: Four modes of supply of services and their relevance for offshoring (source: own elaboration).

\begin{tabular}{lll}
\hline Mode & Description & Relevance for offshoring \\
\hline $\begin{array}{l}\text { Cross-border } \\
\text { supply }\end{array}$ & $\begin{array}{l}\text { Flows of services from one economy into } \\
\text { another economy }\end{array}$ & $\begin{array}{l}\text { High - the main mean of } \\
\text { transmission: telecommunications }\end{array}$ \\
\hline $\begin{array}{l}\text { Consumption } \\
\text { abroad }\end{array}$ & $\begin{array}{l}\text { Service consumer moves from one economy } \\
\text { into another economy in order to be served }\end{array}$ & None \\
\hline $\begin{array}{l}\text { Commercial } \\
\text { presence }\end{array}$ & $\begin{array}{l}\text { Service supplier from one economy } \\
\text { establishes its presence in another } \\
\text { economy in order to provide services }\end{array}$ & $\begin{array}{l}\text { Low - most operations of ABS units } \\
\text { are designed to be delivered outside } \\
\text { a host economy }\end{array}$ \\
$\begin{array}{l}\text { Presence of } \\
\text { natural }\end{array}$ & $\begin{array}{l}\text { Persons from one economy enter into } \\
\text { persons }\end{array}$ & $\begin{array}{l}\text { Low - only in rare cases employees } \\
\text { of ABS units move to another } \\
\text { economy to provide services }\end{array}$ \\
\hline
\end{tabular}


offshoring units, which provide services to clients in other economies. It does not explain the operations of service centres, but rather focuses on the link between a service unit and its clients. Thanks to possibility of transferring services across borders it was possible to established centralised units, which can deliver their output to almost any place in the world. This is enabled by the communications links.

To some extent, firms providing ABS operate in a host economy to be closer to clients. The establishment of a company abroad (mode: "Commercial presence") is typical to firms providing outsourcing solutions and their aim is to follow customers. Large international service providers (e.g. Indian Infosys or French Capgemini) have their units in the key markets for their customers. When providers of services send their employees to work on assignments abroad, it is directly related to the mode: "Presence of natural persons". Those two modes are frequently applied by the same group of firms belonging to the offshore outsourcing category.

Before proceeding to details of the taxonomy of ABS, it is crucial to present their position within services. In doing so, the key approaches to the classification of services will be presented. According to the benchmark International Standard Industrial Classification (ISIC) there are four main categories of services:

- Trade, restaurants and hotels,

- Transport, storage and communications,

- Finance, insurance, real estate and business services,

- Community, social and personal services.

ABS can be considered within the third category above. However, the group is much broader, so ABS constitute merely a subset and require introducing further features allowing to distinguish them from other business services.

ABS, but also business services in large, have been considered as auxiliary operations to key corporate function. From the business perspective, it is important to distinguish two types of functions: core activities and support activities. The first group comprises of primary activities of an enterprise and yielding income (Eurostat, 2019). The same source enlists some of the secondary activities supporting the core functions:

- ICT services

- Administrative and management functions

- Engineering and related technical services

- Research and development

- Distribution and logistics

- Marketing, sales and after sales services

- Other support functions.

The top four types of services presented above are those included in the group of ABS. It means services of high knowledge content dominate the support activities. Moreover, they are subject to the vast internationalisation by applying arrangements allowing to deliver those services abroad either within or outside the boundaries of a firm. 
Classification by the Eurostat (2016) divides knowledge-intensive services into four categories:

- High-tech knowledge-intensive services

- Knowledge-intensive market services (excluding financial intermediation and high-tech services)

- Knowledge-intensive financial services

- Other knowledge-intensive services

The services of our interest are present in the statistic classification in the first and the second group. However, we cannot treat the groups as directly corresponding to KIBS. Even within a short period of time there was evolution of approach towards business services (Table 3 ).

Table 3: Business services according to NACE code (Rev. 1.1) (source: own elaboration based on Eurostat, 2009).

\section{NACE code}

NACE code 72: computer and related activities

72.1 Hardware consultancy

72.2 Software consultancy and supply

72.3 Data processing

72.4 Database activities

72.5 Maintenance and repair of office, accounting and computing machinery

72.6 Other computer-related activities

NACE code 74: other business activities

74.11 Legal activities

74.12 Accounting, book-keeping and auditing activities; tax consultancy

74.13 Market research and public opinion polling

74.14 Business and management consultancy activities

74.2 Architectural and engineering activities and related technical consultancy

74.3 Technical testing and analysis

74.4 Advertising

74.5 Labour recruitment and provision of personnel

74.6 Investigation and security activities

74.7 Industrial cleaning

74.8 Miscellaneous business activities 
The introduction of NACE Rev. 2 made significant step towards better encompassing KIBS in European statistics (Schnabl \& Zenker, 2013). According to the Eurostat (2013) "the business services sector refers to the economic activities covered by NACE Rev. 2 Divisions 62, 69, 71, 73 and 78 and Groups 58.2, 63.1 and 70.2, and the enterprises or parts of enterprises that carry out those activities" (Table 4). The argument for treating the classification as a better reflection of knowledge-intensive services is dropping, previously listed, activities such as 74.6 Investigation and security services or 74.7 Industrial cleaning.

Table 4: Business services according to NACE code (Rev. 2) (source: own elaboration based on Eurostat, 2008).

NACE code

62 Computer programming, consultancy and related activities

69 Legal and accounting activities

71 Architectural and engineering activities; technical testing and analysis

73 Advertising and market research

78 Employment activities

58.2 Software publishing

63.1 Data processing, hosting and related activities; web portals

70.2 Management consultancy activities

An important element of the analysis should be adjusting the perspective to the heterogeneity of advanced services. Indeed, the perception of KIBS as homogenous has been considered as one of the flaws in the conceptual framework (Consoli \& Elche-Hortelano, 2010). They argue that there are various occupational structures and skill requirements within KIBS sector. On the one spectrum of transactional services we can put basic software coding or call centre services, while on the other KIBS and back office functions (Massini \& Miozzo, 2012). As a result of studying various classifications, we achieved an optimal approach to ABS (Table 5) and it is in line with the study presented by (Pina \& Tether, 2016).

However, the available statistics still do not provide sufficient information on foreign ownership of KIBS firms, international flows of inputs and outputs by those firms. Therefore, their usefulness for investigating the recent trends in offshoring of KIBS is pretty limited. Also the methodology of calculating them is far from being robust. When offshoring has been measured using value-added data instead of traditional trade measures, its value was much greater (Atkins, Gilroy, \& Seiler, 2019). It means that not only the value of service offshoring may be underestimated, but also its impact on particular economies. 
Table 5: Types of advanced business services (source: own elaboration based on Pina \& Tether, 2016; UK SIC 2003).

Accountancy (74.12)

Legal services (74.11)

Architectural and engineering activities (74.2)

Business and management consultancy services (74.14)

Software and IT services (72.2)

Specialist design $(74.87 / 2)$ 